\title{
Pengaruh Motivasi Terhadap Minat Berwirausaha Mahasiswa Program Studi Administrasi Bisnis Universitas Telkom
}

\author{
Candra Wijayangka ${ }^{1}$, Budi Rustandi Kartawinata ${ }^{2}$, Bagus Novrianto ${ }^{3}$ \\ Universitas Telkom \\ wijayangka@telkomuniversity.ac.id ${ }^{1}$, budikartawinata@telkomuniversity.ac.id $^{2}$, \\ bgsnvr@yahoo.com ${ }^{3}$
}

\begin{abstract}
Abstrak
Minat berwirausaha merupakan pemusatan perhatian pada wirausaha karena adanya rasa suka dan disertai keinginan mempelajari, mengetahui dan membuktikan lebih lanjut terhadap wirausaha. Minat berwirausaha muncul karena adanya keinginantahuan atas informasi mengenai ilmu kewirausahaan yang kemudian dilanjutkan untuk berpartisipasi secara langsung dalam rangka mencari pengalaman dan akhirnya timbul keinginan untuk memperhatikan pengalaman yang telah didapatkan tersebut. Serta mempunyai perasaan senang dan mempunyai keinginan untuk terlibat dalam kegiatan pengambilan resiko, untuk menjalankan bisnis atau usaha sendiri dengan memanfaatkan peluang-peluang bisnis yang ada, dan menciptakan bisnis baru dengan pendekatan inovatif.Salah satu faktor yang mempengaruhi timbulnya Minat Berwirausaha adalah Motivasi Berwirausaha.

Penelitian ini bertujuan untuk mengetahui pengaruh Motivasi Berwirausaha terhadap Minat Berwirausaha pada mahasiswa Administrasi Bisnis angkatan 2015 Universitas Telkom. Metodologi penelitian kuantitatif dengan analisis deskriptif digunakan dalam penelitian ini adalah kuantitatif dengan jenis penelitian analisis dekriptif. Responden dalam penelitian ini adalah 74 mahasiswa Administrasi Bisnis angkatan 2015 Universitas Telkom dengan metode pengambilan sampel yaitu sampel jenuh.

Hasil penelitian menunjukkan bahwa tanggapan responden terhadap Motivasi Berwirausaha dalam kategori baik dengan skor 79,0\%. Dan tanggapan responden terhadap Minat Berwirausaha dalam kategoribaik dengan skor $80,9 \%$. Kesimpulan penelitian ini adalah Motivasi Berwirausaha berpengaruh dan signifikan secara positif terhadap Minat Berwirausaha dengan skor 43,5\%. Hasil tersebut dapat diartikan bahwa dengan meningkatnya Motivasi Berwirusaha pada mahasiswa akan berpengaruh untuk meningkatkan Minat Berwirausaha mahasiswa.
\end{abstract}

Kata kunci: Motivasi Berwirausaha, Minat Berwirausaha, Wirausaha

\section{Pendahuluan}

Jumlahpenduduk Indonesia menurut data terbitandari Badan Pusat Statistik (BPS) sampai pada tahun 2015 tercatat sebanyak 252.370.792, dari total keseluruhanpendudukterdapat 1,65\%/ 4.164.118 orang adalahpengusaha (BPS, 2015). Jumlah ini tergolong masih sedikit dibandingkan

${ }^{1}$ Korespondensi: Candra Wijayangka. Universitas Telkom. Jl.Telekomunikasi No.1 Bandung. wijayangka@telkomuniversity.ac.id

${ }^{2}$ Korespondensi: Budi Rustandi Kartawinata. Universitas Telkom. Jl.Telekomunikasi No.1 Bandung. budikartawinata@telkomuniversity.ac.id

${ }^{3}$ Korespondensi: Bagus Novrianto. Universitas Telkom. Jl.Telekomunikasi No.1 Bandung. bgsnvr@yahoo.com 
dengan negara lain seperti Singapura sebesar 7\%, Malaysia 5\%, Thailand 4\% dan Amerika sebesar $12 \%$. Untuk menjadi negara dengan perekonomian yang stabil maka sekurang-kurangnya dalam sebuah negara minimal terdapat $2 \%$ pengusaha dari jumlah penduduknya itu berarti Indonesia masih terdapat kekurangan jumlah pengusaha minimal $0,35 \%$ dari jumlah penduduknya atau 883.297 orang, hal ini menunjukkan bahwa peluang menjadi pengusaha masih terbuka luas dengan daya dukung jumlah penduduk terbesar di dunia nomer empat setelah Amerika, China dan India (BPS, 2015). Sementara itu fenomena yang terjadi di kalangan mahasiswa dan mahasiswi Administrasi Bisnis 2015 Universitas Telkom sebagian besar banyak yang berminat berwirausaha. Hasil penyebaran kuisoner oleh peneliti kepada 35 orang responden mahasiswa dan mahasiwi Administrasi Bisnis 2015 Universitas Telkom. Sekitar 88,6\% dari total respondes sebanyak 35 orang tersebut mengatakan berminat berwirausaha dan sekitar 11,4\% nya mengatakan tidak berminat berwirausaha. Meskipun banyak mahasiswa dan mahasiswi Administrasi Bisnis 2015 Universitas Telkom yang berminat berwirausaha, ada beberapa faktor yang menyebabkan terhambatnya keinginan mereka untuk berwirausaha. Sekitar 58,3\% memilih faktor modal menjadi penyebab terhambatnya mereka berwirausaha. Selain itu sekitar $20 \%$ mahasiswa dan mahasiswi memilih faktor kepercayaan diri menjadi penyebab terhambatnya mereka berwirausaha. Sedangkan sisanya memilih faktor ilmu berwirausaha menjadi penyebab terhambatnya mereka berwirausaha. Hal ini menggambarkan bahwa faktor modal menjadi faktor terbesar yang menghambat mahasiswa Administrasi Bisnis 2015

Universitas Telkom dalam berwirausaha.

Kusumastuti (2013:94) menyatakan bahwa faktor motivasi berpengaruh secara positif dan signifikan terhadap minat berwirausaha. Sedangkan penelitian yang dilakukan oleh Tuskeroh (2013) menunjukkan hasil yang berbeda bahwa faktor motivasi tidak berpengaruh secara signifikan terhadap minat berwirausaha. Berdasarkan fenomena yang terjadi diatas, penulis tertarik untuk melakukan penelitian pada mahasiswa Administrasi Bisnis angkatan 2015 Universitas Telkom. Penelitian ini dilakukan untuk melihat dampak dari Motivasi Berwirausaha terhadap Minat Berwirausaha mahasiswa Administrasi Bisnis angkatan 2015 Universitas Telkom.

\section{Literature Review/Related Works Motivasi Berwirausaha Motivasi Berwirausaha}

Riyanti dalam Angen Adhy Sampurna (2015) mendefinisikan bahwa motivasi berwirausaha adalah dorongan yang besar seorang individu untuk bekerja dan sadar bahwa ada keterkaitan anatar wirausaha dengan diri sendiri oleh karena itu individu tersebut memiliki perhatian dan hobi yang lebih dalam melakukan kegiatan usaha mandirinya dengan berbagai ciri kegiatan wirausaha seperti mandiri, fokus pada masa depan, hasrat berusaha mandiri, sampai pada mengembangkankemampuan dan pembuatan rencana yang tepat untuk membuat kegiatasan usaha tersebut berhasil.

\section{Dimensi - Dimensi Motivasi Berwirausaha}

Dalam "Entrepreneur Handbook", dikemukakan beberapa dimensi motivasi berwirausaha menurut Suryana dalam Adhe Octavionica (2016):

1. Dimensi Keuangan, dimana seorang individu akan berusaha untuk menciptakan kesejahteraan dalam hidupmya yang ditandai dengan kepemilikan keuangan dengan cara berwirausaha, sehingga mendapatkan pendapatan yang stabil bahkan berlebih dalam hidupnya.

2. Dimensi Sosial ,dimana ada faktor percaya diri yang tinggi dalam motivasi berwirusaha dari seorang individu, sehingga seorang wirausahawan selalu memiliki tingkat status yang lebih tinggi. 
3. Dimensi Pelayanan, dimana seorang wirausahawan selalu memiliki motivasi untuk menjadi seorang yang menciptakan pekerjaan bagi orang lain, dan bukan sebagai pencari kerja, sehingga dapat menciptakan dan meningkatkan tingkat perekonomian yang tinggi baik di keluarga maupun kerabat di daerahnya.

4. Dimensi Pemenuhan Diri, dimana dalam pemenuhan diri ini, seorang wirausahawan berusahauntuk selalu mandiri dalam setiap kegiatan usahanya dan sngat tidak ingin tergantung pada orang lain, karena itulah esensi dari pemenuhan diri dari seorang pelaku wirausaha.

\section{Pengertian Minat Berwirausaha}

Menurut Munawar dalam Tri Wahyono (2016) minat berwirausaha diartikan sebagai minat mahasiswa untuk melakukan usaha, pemahaman anggaran dan pemahaman tambahan yang dihasilkan dari proses usaha yang digunakan sebagai dasar didalam membuat keputusan.

\section{Dimensi - Dimensi Minat Berwirausaha}

Minat untuk berwirausaha dapat diukur melalui 3 (tiga) macam dimensi yaitu menurut Slameto dalam Adhe Octavionica (2016) :

1. Kognisi, yang meliputi: ilmu wirausaha terhadap keinginan berwirausaha. Kognisi juga dapat diartikan pengetahuan dan persepsi yang diperoleh melalui pengalaman dengan suatu obyek, sikap dan informasi dari berbagai sumber. Ilmu wirausaha ini menjadi sebuah pengetahuan yang mencapai persepsi yang diperoleh para individu sehingga seorang akan percaya akan pengetahuan tersebut. Pengetahuan

2. Emosi, yang meliputi: perasaan senang, ketertarikan dan perhatian terhadap minat berwirausaha. Emosi juga dapat diartikan menggambarkan suasana hati seseorang terhadap obyek. Perasaan dan sikap seseorang merupakan evaluasi menyeluruh terhadap obyek sikap.

3. Konasi, yang meliputi: keinginan, usaha dan keyakinan terhadap minat berwirausaha. Konasi adalah sebuah sikap aktif dari seorang individu untuk melaksanakan tujuan dalam hidupnya yang sesuai dengan arah yang telah ditentukan.

\section{Teori Keterkaitan Motivasi Berwirausaha terhadap Minat Berwirausaha}

Dalam hasil penelitian jurnal Zuhrina Aidha (2016) menjelaskan bahwa terdapat pengaruh signifikan keinginan wirusaha terhadap keinginan berwirusaha yang berbanding lurus, apabila motivasi berwirausaha rendah, maka minat berwirausaha mahasiswa juga rendah, begitu juga sebaliknya apabila motivasi berwirausaha tinggi, maka minat berwirausaha mahasiswanya juga tinggi

\section{Kerangka Pemikiran}

\section{Motivasi Berwirausaha}

a. Alasan Keuangan

b. Alasan Sosial

c. Alasan Pelayanan

d. Alasan Pemenuhan Diri

Sumber: Menurut Suryana

dalam Adhe Octavionica

(2016)

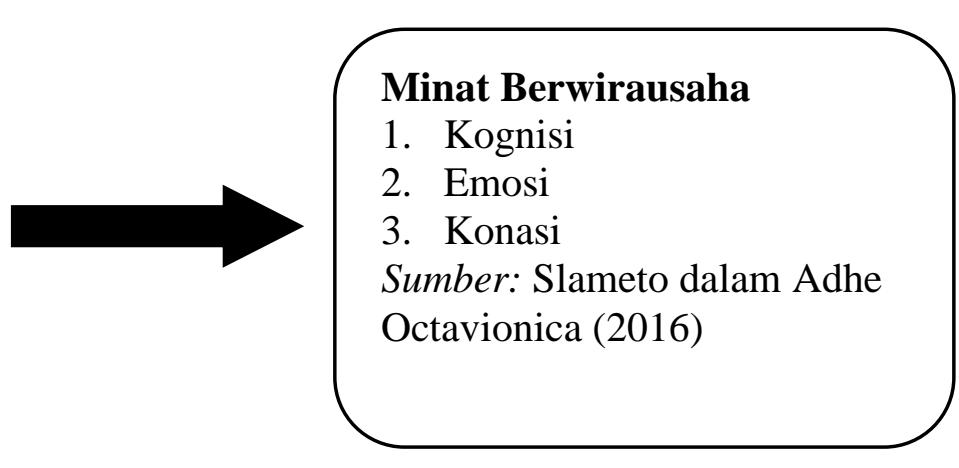

Gambar 1. Kerangka Pemikiran 
Sumber : Olahan Data Penulis

Berdasarkan kerangka pemikiran diatas terdapat dimensi sebagai atribut yang menggambarkan atau mendeskripsikan masing-masing variabel pada peneletian ini. Untuk mengetahui apakah dimensi-dimensi setiap variabel mempunyai hubungan atau tidak

\section{Metode Tulisan/Method}

Dalam pelaksanaan penelitian ini penulis menggunakan jenis penelitian deskriptif dan kausal, Menurut Sugiyono (2015: 254) yang dimaksud dengan penelitian deskriptif ialah penelitian untuk menganalisis data sampai pada taraf pendeskrisian data dimana kesimpulam yang didapat tidak dapat digeneralisir. Sedangkan menurut Sekaran (2013:98), penelitian kausal adalah penelitian dimana seoarang peneliti ingin menemukan penyebab dari satu atau lebih masalah, dengan kata lain diadakan studi kausal adalah untuk menyakatan ada pengaruh antara variabel terikat dan variabel bebas

Karya ilmih dalam bentuk hasil penelitian ini menggunakan metode kuantitatif. Menurut Sugiyono (2015:11) peneltiian kuantitatif adalah metode dengan cara pandang positivsme dengan tujuan menelitia populasi atau sampel sebagai data dan menggunakan instrumen penelitian yang bersifat kuantitatif. atau statistik, dengan tujuan untuk menguji hipotesis yang telah ditetapkan

\section{Hasil}

\section{Uji Signifikan Parsial}

Untuk membuktikan apakah Motivasi Berwirausaha memiliki pengaruh yang signifikan terhadapMinat Berwirausaha, maka dilakukan pengujian dengan hipotesis statistik sebagai berikut:

H0: $t_{\text {hitung }}<t_{\text {tabel }}$, Motivasi Berwirausaha tidak berpengaruh terhadap Minat Berwirausaha mahasiswa Administrasi Bisnis angkatan 2015 Universitas Telkom

$\mathrm{H} 1: \mathrm{t}_{\text {hitung }} \geq \mathrm{t}_{\text {tabe }}$, Motivasi Berwirausaha berpengaruh terhadap Minat Berwirausaha mahasiswa Administrasi Bisnis angkatan 2015 Universitas Telkom

Kriteria Minat Berwirausaha merupakan batasan dari nilai tabel dengan memperhatikan derajat kebebasan (dk) dan tingkat signifikansi sehingga dari batasan ini dapat disimpulkan apakah $\mathrm{H}_{0}$ diterima atau ditolak.

Berdasarkan Tabel 4.22 nilai thitung diperoleh sebesar 7,943. Sedangkan tabel pada tingkat signifikansi $5 \%$ dan $n=73$ adalah 1994 . Karena $t_{\text {hitung }}(7,943)>t_{\text {tabel }}(1,994)$ maka $\mathrm{H}_{0}$ ditolak dan $\mathrm{H}_{1}$ diterima.

Berdasarkan Tabel 4.22 juga diperoleh nilai signifikasi sebesar 0,000 dimana nilai signifikasi penelitian < 0,05 maka dapat diartikan variabel empowerment mempunyai nilai yang sangat signifikan secara posisitf terhadap quality of worklife.

Hasil pengujian ini dapat diartikan bahwa dengan adanya empowerment di dalam perusahaan akan meningkatkan quality of worklife pada karyawan.

\section{Analisis Deskriptif \\ Tanggapan Responden terhadap Motivasi Berwirausaha}

Penelitian ini menggunakan 74 responden yang disebarkan kepada mahasiswa Administrasi Bisnis angkatan 2015 Universitas Telkom . Berdasarkan hasil pengujian yang dilakukan diketahui bahwa posisi variabel Motivasi Berwirausaha pada garis kontinum termasuk dalam kategori Baik. Sehingga secara keseluruhan, Motivasi Berwirausaha pada mahasiswa Administrasi Bisnis angkatan 2015 Universitas Telkom sudah baik dengan skor 79,0\%. 


\section{Tanggapan Responden terhadap Minat Berwirausaha}

Penelitian ini menggunakan 74 responden yang disebarkan kepada mahasiswa Administrasi Bisnis angkatan 2015 Universitas Telkom. Berdasarkan hasil pengujian yang dilakukan diketahui bahwa posisi variabe 1 Minat Berwirausaha pada garis kontinum termasuk dalam kategori baik. Sehingga secara keseluruhan, Minat Berwirausaha pada mahasiswa Administrasi Bisnis angkatan 2015 Universitas Telkom baik dengan skor 80,9\%.

\section{Analisis Regresi Linear Sederhana}

Analisis regresi sederhana digunakan untuk menentukan seberapa kuatnya pengaruh variabel independen (X) yaitu Motivasi Berwirausaha terhadap variabel dependennya (Y) yaitu Minat Berwirausaha. Berikut terdapat tabel koefisien hasil Analisa regresi menggunakan SPSS 22, yaitu:

\section{Tabel 1. Hasil Perhitungan Koefisien Regresi}

Coefficients $^{\mathrm{a}}$

\begin{tabular}{|lc|r|r|r|r|r|}
\hline \multirow{2}{*}{ Model } & \multicolumn{2}{|c|}{$\begin{array}{c}\text { Unstandardized } \\
\text { Coefficients }\end{array}$} & \multicolumn{2}{c|}{$\begin{array}{c}\text { Standardized } \\
\text { Coefficients }\end{array}$} & & \\
\cline { 3 - 5 } & \multicolumn{1}{|c|}{$\mathrm{B}$} & Std. Error & \multicolumn{1}{|c|}{ Beta } & $\mathrm{t}$ & \multicolumn{1}{c|}{ Sig. } \\
\hline 1 & (Constant) & 1.148 & .329 & & 3.488 & .001 \\
& Motivasi & .707 & .095 & .659 & 7.442 & .000 \\
\hline
\end{tabular}

a. Dependent Variable: Minat

Sumber: Hasil Pengolahan SPSS 22

Berdasarkan hasil perhitungan pada tabel di atas, diperoleh bentuk persamaan regresi linier sederhana sebagai berikut :

$\mathrm{Y}=\mathbf{1 , 1 4 8}+\mathbf{0 , 7 0 7} \mathrm{X}+\mathrm{e}$

Tanda koefisien regresi variabel bebas menunjukkan arah hubungan dari variabel yang bersangkutan dengan Minat Berwirausaha. Koefisien regresi untuk variabel bebas $\mathrm{X}$ bernilai positif, menunjukkan adanya hubungan yang searah antara Motivasi Berwirausaha $(\mathrm{X})$ dengan Minat Berwirausaha (Y). Koefisien regresi variabel X sebesar 0,707 mengandung arti untuk setiap pertambahan Motivasi Berwirausaha (X) sebesar satu satuan akan menyebabkan meningkatnya Minat Berwirausaha (Y) sebesar 0,707 satuan.

\section{KoefisienDeterminasi}

\section{Tabel 2. KoefisienDeterminasi}

Model Summary

\begin{tabular}{|l|r|r|r|r|}
\hline Model & \multicolumn{1}{|c|}{$\mathrm{R}$} & R Square & $\begin{array}{c}\text { Adjusted } \\
\text { R Square }\end{array}$ & $\begin{array}{r}\text { Std. Error of } \\
\text { the Estimate }\end{array}$ \\
\hline 1 & $.659^{\mathrm{a}}$ & .435 & .427 & .47795 \\
\hline
\end{tabular}

a. Predictors: (Constant), Motivasi

Sumber: Hasil Pengolahan Data SPSS

Dapat dilihat dari tabel tersebut bahwa diperoleh koefisien determinasi $\left(\mathrm{R}^{2}\right)$ sebesar 0,435 . Artinya ada pengaruh antara variabel Motivasi Berwirausaha terhadap Minat Berwirausaha sebesar $43,5 \%$ sedangkan sisanya $56,5 \%$ dipengaruhi oleh variabel-variabel lain yang tidak peneliti libatkan dalam penelitian ini. 


\section{Simpulan}

Berdasarkan hasil penelitian dan analisis pembahasan yang telah dilakukan oleh peneliti pada bab sebelumnya, selanjutnya peneliti menyimpulkan beberapa hal penting dari hasil penelitian ini, yaitu:

1. Motivasi berwirausaha S1 Administrasi Bisnis Universitas Telkom angkatan 2015 termasuk dalam kategori yang baik.

2. Minat berwirausaha S1 Administrasi Bisnis Universitas Telkom angkatan 2015 termasuk dalam kategori yang baikatautinggi.

3. Terdapat pengaruh positif dan signifikan antara motivasi berwirausaha terhadap minat berwirausaha mahasiswa S1 Administrasi Bisnis Universitas Telkom angkatan 2015. Hal tersebut berdasarkan hasil perhitungan analisis regresi dengan nilai thitung $>$ tabel atau nilai sig $<0,05$.

Hasil penelitian yang telah dikemukakan, maka untuk meningkatkan minat berwirausaha mahasiswa dimasa yang akan datang diajukan saran-saran sebagai berikut:

1. Saran untuk universitas

Universitas perlu meningkatkan kualitas pendidikan kewiusahaan dan memotivasi mahasiswanya untuk menjadi wirausaha dengan cara:

a. Universitas memperbaiki sistem pendidikan yang berbasis pada peningkatan mutu dan kualitas mahasiswa untuk menjadi bekal berwirausaha.

b. Universitas mengadakan pelatihan kewirausahaan bagi para mahasisawa untuk meningkatkan pengalaman dan pengetahuan berwirausaha.

c. Universitas memberikan bantuan modal kepada mahasiswa untuk membuka atau mengembangkan usaha yang direncakan atau dikembangkannya.

d. Universitas memberikan bimbingan dan pendampingan secara intensif kepada mahasiswa yang mempunyai keinginan untuk berwirausaha.

2. Saran untuk penelitian mendatang :

a. Menambah variabel independen yang diduga adanya mengapur minat berwirusaha seperti keluarga dan lingkungan sosial, sehingga penelitian mengenai minat berwirausaha akan berkembang.

b. Penelitian selanjutnya hendaknya dilakukan dalam universitas dengan jumlah responden yang lebih banyak sehingga dapat dibandingkan.

c. Penelitian selanjutnya hendaknya mencari ruang lingkup populasi yang berbeda dan lebih luas dari populasi dalam penelitian ini. Sampel yang digunakan hendaknya juga lebih banyak daripada sampel dalam penelitian ini, dengan demikian dapat semakin mendeskripsikan secara spesifik mengenai minat berwirausaha

\section{Daftar Pustaka}

Aidha, Zuhrina. (2016). Pengaruh Motivasi Terhadap Minat Berwirausaha Mahasiswa Fakultas Kesehatan Universitas Islam Negeri Sumatera Utara

Kusumastuti, Rita. 2013. Pengaruh Motivasi dan Pengetahuan Undang-Undang No.5 tahu2011 tentang Akuntan Publik terhadap Minat Mahasiswa Akuntansi Mengikuti Pendidikan Profesi Akuntansi (PPAk) (Studi Kasus pada Mahasiswa Akuntansi Universitas Negeri Yogyakarta). S1 thesis, FakultasEkonomi.

Octavionica, Adhe. (2016). Pengaruh Motivasi Berwirausaha Serta Lingkungan Internal dan Lingkungan Eksternal Terhadap Minat Berwirausaha Mahasiswa Pendidikan Ekonomi Universitas Lampung. 


\section{eCo-Buss}

Sampurna, Angen Adhy (2015) Minat Berwirausaha Ditinjau Dari Motivasi Berwirausahadan Prestasi BelajarMata Pelajaran Kewirausahaan Pada Siswa Kelas XI Program Keahlian Karawitandan Seni Tari SMK Negeri 8 Surakarta Tahun Ajaran 2014/2015.

Sekaran, Uman, dan Bougie, Roger. (2013). Research Methods for Bussiness. United Kingdom: Jhon Wiley \& Sons Ltd.

Sugiyono. (2015). MetodePenelitian dan Pengembangan. Bandung: Alfabeta.

Tuskeroh. 2013. Pengaruh Motivasi dan Mental Berwirausaha pada Mahasiswa Akuntansi Universitas Maritim Raja Ali Haji. Skripsi.

Wahyono, Tri (2016) Pengaruh Entrepreneur Knowledge, Motivasidan Praktek Bisnis Nabi Muhammad SAW Terhadap Minat Berwirausaha (Studi Kasus Mahasiswa Muslimdi Salatiga) 